Author affiliations appear at the end of this article.

Published online ahead of print at www.jco.org on June 13, 2016.

Supported by Active Biotech.

C.S. and A.A. contributed equally to this work as first co-authors.

Presented in part at the European Cancer Congress 2015, Vienna, Austria

September 25-29, 2015.

Authors' disclosures of potential conflicts of interest are found in the article online at www.jco.org. Contributions are found at the end of this article.

Clinical trial information: NCT01234311.

Corresponding author: Michael Carducci, MD, The Johns Hopkins University School of Medicine, 1650 Orleans St, CRB1

1M59, Baltimore, MD 21287-1000; e-mail: carducci@jhmi.edu

C 2016 by American Society of Clinical Oncology

0732-183X/16/3422w-2636w/\$20.00

DOI: 10.1200/JCO.2016.66.9697

\title{
Randomized, Double-Blind, Placebo-Controlled Phase III Study of Tasquinimod in Men With Metastatic Castration-Resistant Prostate Cancer
}

Cora Sternberg, Andrew Armstrong, Roberto Pili, Siobhan Ng, Robert Huddart, Neeraj Agarwal, Denis Khvorostenko, Olexiy Lyulko, Arija Brize, Nicholas Vogelzang, Rémy Delva, Mihai Harza, Anastasios Thanos, Nicholas James, Patrick Werbrouck, Martin Bögemann, Thomas Hutson, Piotr Milecki, Simon Chowdhury, Enrique Gallardo, Gilberto Schwartsmann, Jean-Christophe Pouget, Frédérique Baton, Thore Nederman, Helen Tuvesson, and Michael Carducci

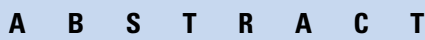

\section{Purpose}

Tasquinimod, a novel oral therapy targeting the tumor microenvironment, significantly improved progression-free survival (PFS) in a randomized, placebo-controlled phase II trial in men with metastatic castration-resistant prostate cancer (mCRPC). This phase III study was conducted to confirm the phase $\mathrm{II}$ results and to detect an overall survival (OS) benefit.

\section{Patients and Methods}

Men with chemotherapy-naïve mCRPC and evidence of bone metastases were assigned (2:1) to receive tasquinimod once per day or placebo until progression or toxicity. The primary end point was radiographic PFS (rPFS; time from random assignment to radiologic progression or death) per Prostate Cancer Working Group 2 criteria and RECIST 1.1. The study had 99.9\% power to detect an rPFS hazard ratio (HR) of 0.6 with a two-sided alpha error of .05 and $80 \%$ power to detect a target HR of 0.8 for OS, the key secondary end point.

\section{Results}

In all, 1,245 patients were randomly assigned to either tasquinimod ( $n=832$ ) or placebo $(n=413)$ between March 2011 and December 2012 at 241 sites in 37 countries. Baseline characteristics were balanced between groups: median age, 71 years; Karnofsky performance status $\geq 90 \%, 77.3 \%$; and visceral metastases, $21.1 \%$. Estimated median rPFS by central review was 7.0 months $(95 \% \mathrm{Cl}, 5.8$ to 8.2 months) with tasquinimod and 4.4 months ( $95 \% \mathrm{Cl}, 3.5$ to 5.5 months) with placebo (HR, 0.64 ; $95 \% \mathrm{Cl}, 0.54$ to $0.75 ; P<.001)$. Median OS was 21.3 months ( $95 \% \mathrm{Cl}, 19.5$ to 23.0 months) with tasquinimod and 24.0 months $(95 \% \mathrm{Cl}, 21.4$ to 26.9 months) with placebo (HR, $1.10 ; 95 \% \mathrm{Cl}, 0.94$ to $1.28 ; P=.25)$. Grade $\geq 3$ adverse events were more frequent with tasquinimod $(42.8 \% \vee 33.6 \%)$, the most common being anemia, fatigue, and cancer pain.

\section{Conclusion}

In chemotherapy-naïve men with mCRPC, tasquinimod significantly improved rPFS compared with placebo. However, no OS benefit was observed.

\section{J Clin Oncol 34:2636-2643. (c) 2016 by American Society of Clinical Oncology}

\section{INTRODUCTION}

Treatment options for metastatic castrationresistant prostate cancer (mCRPC) have expanded with the introduction of several new agents that delay disease progression and improve overall survival (OS). These include second-generation androgen-directed therapies, radium-223, sipuleucel- $T$, and the taxanes cabazitaxel and docetaxel. Despite these advances,
mCRPC remains incurable, and survival benefits typically achieved with newer agents are modest while resistance remains common. ${ }^{1-7}$ New agents with alternative mechanisms of action that further improve survival while minimizing toxicity are needed.

The tumor microenvironment is increasingly recognized as playing a major role in the formation and growth of metastases. ${ }^{8}$ In addition, the host microenvironment has been shown to promote prostate cancer invasion, systemic spread, bone 
colonization, and osteoblastic metastasis. ${ }^{9}$ Drugs that target the tumor microenvironment therefore offer a potentially new approach in the treatment of advanced prostate cancer. ${ }^{10}$ Tasquinimod (ABR-215050; Active Biotech, Lund, Sweden) is an oral immunotherapy with demonstrated effects on the tumor microenvironment that counteract tumor growth. ${ }^{11,12}$ One molecular target of tasquinimod is the immunomodulatory protein S100A9, which plays a role in the accumulation and function of innate immune cells, specifically regulatory myeloid cells. ${ }^{11-13}$ Targeting regulatory myeloid cells within the tumor microenvironment leads to decreased immune suppression and angiogenesis and prevention of metastasis development. Tasquinimod may also reduce angiogenesis by downregulation of HIF1-controlled genes via interaction with histone deacetylases. ${ }^{14}$

In a randomized, placebo-controlled phase II study in men with mCRPC, tasquinimod significantly improved progressionfree survival (PFS; median, 7.6 v 3.3 months; hazard ratio [HR], $0.57 ; P<.01) .{ }^{15}$ In long-term follow-up, multivariate analysis indicated that the PFS improvement may be associated with improved OS, particularly in patients with bone metastases. ${ }^{16}$ The objective of this phase III study was to confirm the benefit of tasquinimod in delaying disease progression and improving OS in men with mCRPC.

\section{PATIENTS AND METHODS}

\section{Patients}

Eligible patients had histologically confirmed prostate adenocarcinoma with evidence of bone metastases, serum testosterone $\leq 50 \mathrm{ng} / \mathrm{dL}$, disease progression (increasing serum prostate-specific antigen [PSA] as defined by the Prostate Cancer Working Group 2 [PCWG2], ${ }^{17}$ progression of soft tissue metastasis, or bone disease progression), and Karnofsky performance status $\geq 70 \%$. Concurrent use of luteinizing hormonereleasing hormone agonists or antagonists and bone agents (denosumab or bisphosphonates) was permitted.

No cytotoxic chemotherapy within 2 years or previous anticancer therapy within 4 weeks ( 2 weeks for sipuleucel-T) of random assignment was allowed. Prior enzalutamide or abiraterone was permitted. Other exclusion criteria included presence of prostate cancer pain requiring opiate analgesics, systemic exposure to ketoconazole, and ongoing corticosteroid treatment equivalent to a prednisolone or prednisone dose of $>10 \mathrm{mg} /$ day.

\section{Study Design}

This multinational, randomized, double-blind, placebo-controlled phase III study was conducted at 241 sites in 37 countries (Appendix Table $\mathrm{A} 1$, online only). Patients were randomly assigned in a 2:1 ratio to receive tasquinimod or placebo by using an interactive voice response system. Random assignment was stratified by Karnofsky performance status ( $\geq 90 \% v<90 \%$ ), presence or absence of visceral disease (all metastatic soft tissue except lymph nodes and local recurrence), and geographic region (North America, Europe, the Middle East, Africa, Asia-Pacific, and Latin America). Tasquinimod or placebo was administered orally at a starting dose of $0.25 \mathrm{mg} /$ day for at least 2 weeks. ${ }^{18}$ If tolerability was established, the dose was escalated to $0.5 \mathrm{mg} /$ day for 2 weeks and then to $1 \mathrm{mg} /$ day. Patients unable to tolerate the escalated doses could continue in the study at their maximum tolerated dose. Treatment continued until symptomatic disease progressed so that it required alternative antitumor therapy or until poor tolerability occurred. After the end of treatment, patients continued follow-up with visits every 3 months until death or until 727 patients had reached the survival end point.
The study was approved by the institutional review boards or ethics committees at each participating center and was conducted in accordance with the Declaration of Helsinki. All patients provided written informed consent before study entry.

\section{End Points}

The primary end point was radiographic PFS (rPFS), the time from random assignment to radiologic progression or death, whatever the cause. Radiographic progression was defined as soft tissue progression (RECIST 1.1), ${ }^{19}$ bone progression detected with confirmatory bone scans (PCWG2), ${ }^{7}$ or radiographically confirmed spinal cord compression or fracture as a result of malignant progression. Soft tissue lesions were evaluated by computed tomography or magnetic resonance imaging scans by the investigator. All scans underwent independent central review, with reviewers blinded to study treatment and investigator assessments.

The key secondary end point was OS, defined as time from random assignment to death. Other prespecified secondary end points included time to radiologic progression, time to symptomatic progression, time to PSA progression, time to initiation of further cytotoxic therapy, time to opiate use, and time to deterioration of quality-of-life (QoL) measure (Functional Assessment of Cancer Therapy-Prostate [FACT-P]). Safety was assessed on the basis of physical examination, vital signs measurements, clinical laboratory analyses, and adverse events (AEs; coded using Medical Dictionary for Regulatory Activities [MedDRA]; graded using Common Terminology Criteria for Adverse Events [CTCAE] version 4.0).

\section{Statistical Analysis}

The planned sample size of 1,200 patients ( 800 in the tasquinimod arm and 400 in the placebo arm) provided $99.9 \%$ power at a two-sided significance level of 0.05 to detect an HR of 0.6 for the primary end point of rPFS, corresponding to an increase in median PFS from 3.4 to 5.7 months. The study was also designed to detect an HR of 0.8 for the key secondary end point of OS, corresponding to an increase in median OS from 22 to 27.5 months. Specifying a two-sided significance level of 0.05 , the study had $80 \%$ power to detect the OS difference after 727 deaths had been observed. The OS end point comparisons incorporated group sequential design involving two interim analyses (at 473 and 582 events) and a final analysis at 727 events using O'Brien-Fleming stopping boundaries ${ }^{20}$ : first interim analysis, $P \leq .0109$; second interim analysis, $P \leq .0212$; and final analysis, $P \leq .0422$. rPFS was analyzed at the first planned interim analysis for OS (after 473 events). If the comparison of rPFS reached statistical significance $(P \leq .05)$, the first comparison of OS was performed; however, the results were not reported until the final analysis.

A stratified log-rank test by factors at random assignment was used to compare rPFS, OS, and the time-to-event secondary end points for tasquinimod versus placebo (analysis of PSA doubling time was not stratified). To describe time-to-event variables, Kaplan-Meier curves and life tables by treatment group were generated, and CIs were calculated. ${ }^{21}$ Patients who did not experience an event were censored at the date of their last adequate assessment, previous assessment, last visit, or death, depending on the end point and analysis. Treatment effect was estimated by calculating the HR and its $95 \%$ CI from a Cox proportional hazards model stratified by factors at random assignment. For rPFS and OS, Cox proportional hazards models were performed for predefined subgroups and multivariate analyses. In the latter analyses, after testing each prespecified prognostic factor with a univariate analysis, a backward selection approach was used. Treatment was always included in the models.

All efficacy end points were analyzed by planned treatment in the intent-to-treat population (all randomly assigned patients, regardless of whether any study treatment dosing was completed). The safety analysis population comprised all patients who received at least one dose of study treatment. Safety was analyzed according to treatment received. All statistical analyses were performed by using SAS version 9.2 (SAS Institute, Cary, NC). 


\section{RESULTS}

\section{Patient Disposition}

Of 1,645 patients screened, 1,245 were randomly assigned to receive tasquinimod $(n=832)$ or placebo $(n=413)$ between March 29, 2011, and December 7, 2012 (Appendix Table A1). Two patients from each group did not receive treatment after random assignment (Fig 1). Baseline characteristics were generally well balanced between the groups (Table 1). A greater proportion of patients in the tasquinimod group had higher levels of baseline tumor pain (Visual Analog Scale $>4: 18.6 \% v 14.5 \%$ ). Median time since diagnosis was shorter in the tasquinimod group than in the placebo group (45.7 $v 57.7$ months).

At final analysis (cutoff date: February 13, 2015), median follow-up was 30.0 months in the tasquinimod arm and 30.7 months in the placebo arm, and $96.1 \%$ of patients had discontinued treatment. The most common reasons for discontinuation (tasquinimod $v$ placebo) were radiographic progression $(23.8 \% \vee 36.5 \%)$, symptomatic progression requiring new anticancer therapy $(21.3 \% \vee 18.8 \%)$, and poor tolerability or AEs (17.9\% $v 8.8 \%$; Fig 1$)$.

\section{Efficacy}

The final analysis of the primary end point of rPFS was performed at the time of the first interim analysis of OS. Radiographic progression by central review, or death, occurred in 396 patients $(48 \%)$ in the tasquinimod group and in 258 patients $(62 \%)$ in the placebo group. Estimated median rPFS was 7.0 months (95\% CI, 5.8 to 8.2 months) for tasquinimod and 4.4 months (95\% CI, 3.5 to 5.5 months) months for placebo, corresponding to a $36 \%$ reduction in the risk of radiographic progression or death with tasquinimod versus placebo (HR, 0.64; 95\% CI, 0.54 to $0.75 ; P<.001$; Fig 2 A). Similar results were seen in the assessment by local review: estimated median rPFS was 5.7 months (95\% CI, 5.5 to 6.2 months) and 4.1 months (95\% CI, 3.1 to 5.1 months), respectively (HR 0.69 ; $95 \% \mathrm{CI}, 0.60$ to 0.80 ; $P<.001)$.

OS results were not significant at either of the two interim analyses and, because no safety concerns were raised, the Data and Safety Monitoring Board recommended continuation of the study according to the protocol. At final analysis of OS, 492 deaths $(59.1 \%)$ had occurred in the tasquinimod group and 238 deaths $(57.6 \%)$ had occurred in the placebo group. Tasquinimod did not improve OS compared with placebo (median OS, 21.3 months [ $95 \%$ CI, 19.5 to 23.0 months] with tasquinimod and 24.0 months [95\% CI, 21.4 to 26.9 months] with placebo; HR, 1.10 ; $95 \% \mathrm{CI}, 0.94$ to $1.28 ; P=.25$; Fig $2 \mathrm{~B})$. The rPFS and OS results were consistent when examined across predefined patient subgroups without evidence of significant heterogeneity (Fig 3).

In general, secondary end points that favored tasquinimod over placebo included the radiographic- and PSA-based outcomes (Table 2 and Appendix Table A2, online only). In contrast, symptomatically assessed end points, such as time to symptomatic progression, time to opiate use, and deterioration in QoL, favored placebo. Time to initiation of salvage therapy was longer with tasquinimod than with placebo (11.4 $v 8.1$ months; $P=.001)$, as was time to initiation of further cytotoxic therapy $(25.8 v$ 16.0 months; $P=.021)$.

One quarter of patients (315 [25.3\%] of 1,245) had undergone orchiectomy, and most patients (1,178 [94.6\%] of 1,245) had received hormonal therapy pre-enrollment (mostly bicalutamide, flutamide, and luteinizing hormone-releasing hormone analogs). In contrast, only a few patients had received prior abiraterone (five patients $[0.6 \%]$ in the tasquinimod group $v$ seven patients [1.7\%] in the placebo group) or enzalutamide (zero $v$ one $[0.2 \%]$ ). These treatments were more commonly

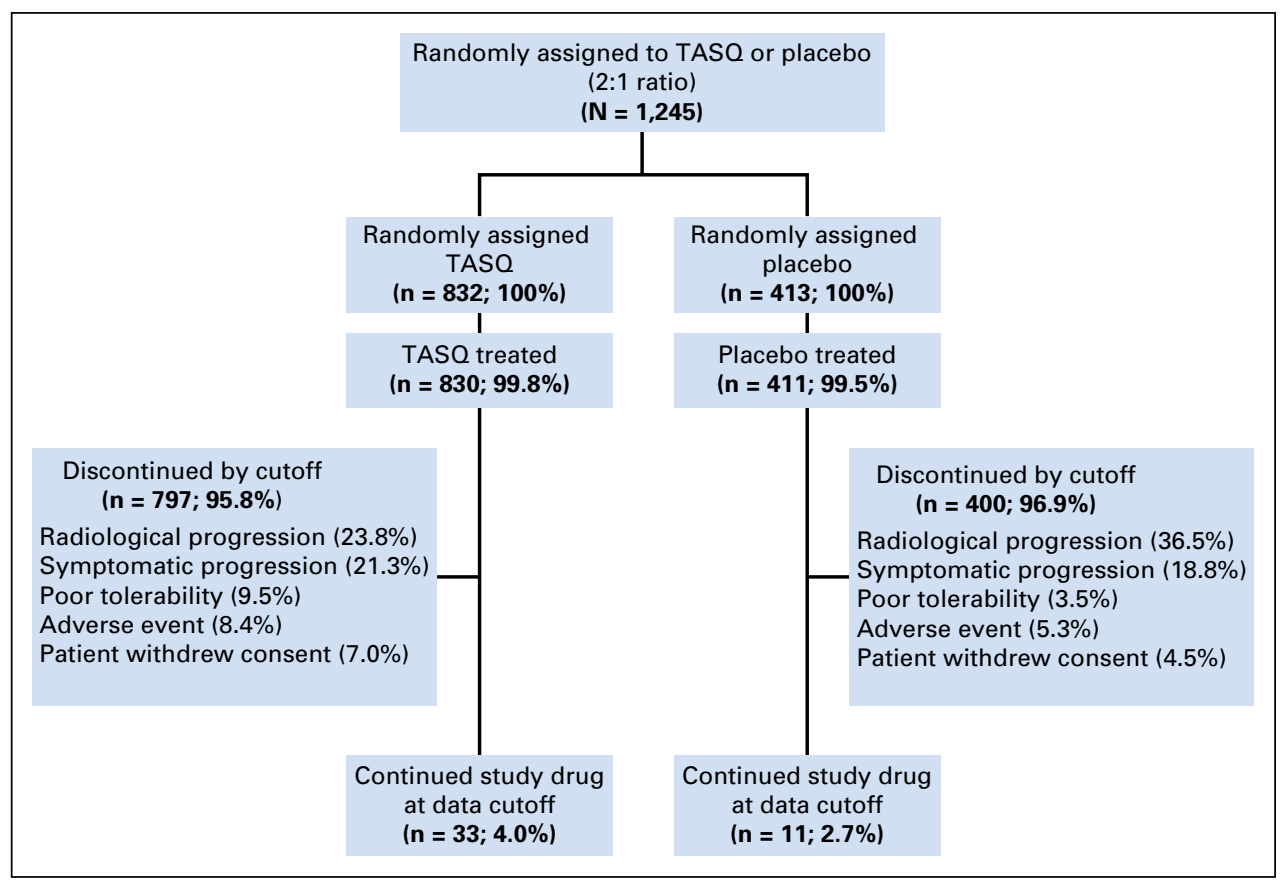

Fig 1. CONSORT diagram. TASQ, tasquinimod. 


\begin{tabular}{|c|c|c|c|c|}
\hline \multirow[b]{2}{*}{ Characteristic } & \multicolumn{2}{|c|}{$\begin{array}{l}\text { Tasquinimod } \\
(\mathrm{n}=832)\end{array}$} & \multicolumn{2}{|c|}{$\begin{array}{l}\text { Placebo } \\
(n=413)\end{array}$} \\
\hline & No. & $\%$ & No. & $\%$ \\
\hline $\begin{array}{l}\text { Median age, years } \\
\text { (range) }\end{array}$ & \multicolumn{2}{|c|}{$71.0(43-92)$} & \multicolumn{2}{|c|}{$71.0(48-92)$} \\
\hline \multicolumn{5}{|l|}{ Age group (years) } \\
\hline$\leq 65$ & 214 & 25.7 & 106 & 25.7 \\
\hline $66-75$ & 371 & 44.6 & 186 & 45.0 \\
\hline $76-80$ & 144 & 17.3 & 64 & 15.5 \\
\hline$>80$ & 103 & 12.4 & 57 & 13.8 \\
\hline \multicolumn{5}{|l|}{ Race* $^{*}$} \\
\hline White & 729 & 87.6 & 359 & 86.9 \\
\hline Black & 20 & 2.4 & 8 & 1.9 \\
\hline Asian & 46 & 5.5 & 27 & 6.5 \\
\hline Other & 37 & 4.4 & 18 & 4.4 \\
\hline \multicolumn{5}{|l|}{ Ethnicity } \\
\hline Hispanic/Latino & 97 & 11.7 & 42 & 10.2 \\
\hline Non-Hispanic/Latino & 735 & 88.3 & 371 & 89.8 \\
\hline $\begin{array}{l}\text { Median time since } \\
\text { diagnosis, } \\
\text { months (range) }\end{array}$ & \multicolumn{2}{|c|}{$45.7(0.1-299.6)$} & \multicolumn{2}{|c|}{$57.7(0.3-319.9)$} \\
\hline \multicolumn{5}{|l|}{$\begin{array}{l}\text { Karnofsky performance } \\
\text { statust }\end{array}$} \\
\hline$<90 \%$ & 187 & 22.5 & 95 & 23.0 \\
\hline$\geq 90 \%$ & 645 & 77.5 & 318 & 77.0 \\
\hline \multicolumn{5}{|l|}{$\begin{array}{l}\text { Geographic region of } \\
\text { enrollment } \dagger\end{array}$} \\
\hline North America & 143 & 17.2 & 72 & 17.4 \\
\hline $\begin{array}{l}\text { Europe/Middle East/ } \\
\text { Africa }\end{array}$ & 505 & 60.7 & 254 & 61.5 \\
\hline Asia-Pacific & 94 & 11.3 & 46 & 11.1 \\
\hline Latin America & 90 & 10.8 & 41 & 9.9 \\
\hline \multicolumn{5}{|l|}{ Tumor pain (VAS)‡ } \\
\hline 0 & 371 & 44.6 & 195 & 47.2 \\
\hline $1-3$ & 286 & 34.4 & 157 & 38.0 \\
\hline $4-10$ & 155 & 18.6 & 60 & 14.5 \\
\hline $\begin{array}{l}\text { Median PSA, } \mu g / L \\
\text { (range) }\end{array}$ & \multicolumn{2}{|c|}{$54.3(0.6-8,710.7)$} & \multicolumn{2}{|c|}{$50.1(0.2-5,679.5)$} \\
\hline $\begin{array}{l}\text { Gleason score of } 8 \text { to } 10 \\
\text { at diagnosis }\end{array}$ & 398 & 47.8 & 190 & 46.0 \\
\hline $\begin{array}{l}\text { Visceral disease } \\
\text { present }{ }^{\dagger}\end{array}$ & 176 & 21.2 & 87 & 21.1 \\
\hline \multicolumn{5}{|l|}{ Location of metastases } \\
\hline Visceral§ & 161 & 19.4 & 76 & 18.4 \\
\hline Bone & 824 & 99.0 & 409 & 99.0 \\
\hline Node & 297 & 35.7 & 179 & 43.3 \\
\hline \multicolumn{5}{|l|}{ No. of bone metastases } \\
\hline$<10$ & 377 & 45.3 & 194 & 47.0 \\
\hline$\geq 10$ & 447 & 53.7 & 215 & 52.1 \\
\hline $\begin{array}{l}\text { Previous second- } \\
\text { generation } \\
\text { hormonal therapy } \uparrow\end{array}$ & 65 & 7.8 & 48 & 11.6 \\
\hline
\end{tabular}

Abbreviations: PSA, prostate-specific antigen; VAS, Visual Analog Scale.

*Data missing for one patient in the placebo group.

†According to interactive voice response system data, except for Europe, Middle East, and Asia-Pacific subcategories for geographic region.

₹Data missing for 20 patients in the tasquinimod group and one patient in the placebo group.

$\S$ According to electronic case report form data. Indicated location does not exclude other sites.

१Abiraterone, enzalutamide, ketoconazole, or any other second-generation hormonal treatment.

available during the follow-up period after withdrawal from study treatment and were used more in the placebo group (abiraterone, 209 [25\%] v 127 [31\%]; enzalutamide, 66 [8\%] $v 48$ [12\%]). More than one third of patients received docetaxel after the study (281 [34\%] v $166[40 \%])$.

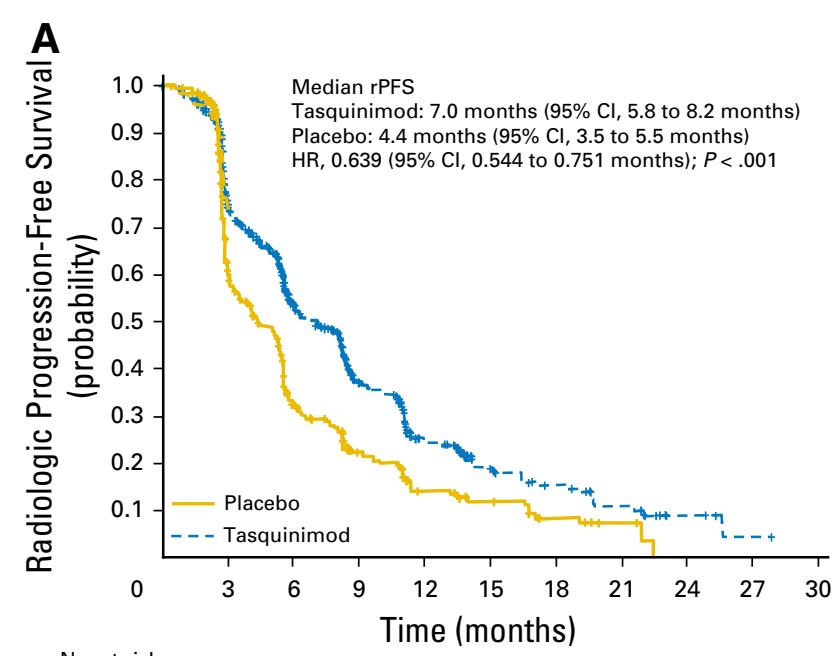

$\begin{array}{lccccccccr}\text { No. at risk } & & & & & & & & \\ \text { TASO } & 396 & 235 & 142 & 71 & 35 & 25 & 13 & 5 & 1 \\ \text { Placebo } & 181 & 80 & 45 & 22 & 15 & 8 & 3 & & \end{array}$

B

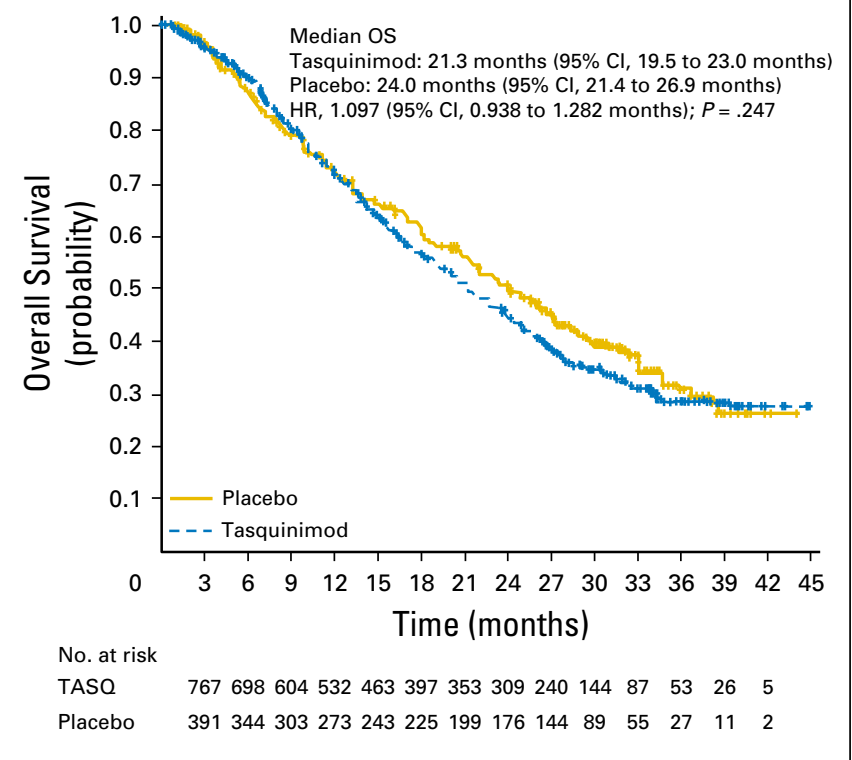

Fig 2. Kaplan-Meier analysis of $(A)$ radiologic progression-free survival (rPFS; central review) and (B) overall survival (OS). HR, hazard ratio; TASQ, tasquinimod.

\section{Drug Exposure and Safety}

Overall median treatment duration was 137 days (range, 1 to 1,377 days) for tasquinimod and 133 days (range, 8 to 1,179 days) for placebo, and most patients ( $82 \%$ and $92 \%$, respectively) escalated to the maximum dose of $1 \mathrm{mg} /$ day.

The proportion of patients with at least one dose reduction from maximum dose was higher in the tasquinimod group than in the placebo group (17.5\% $v 5.6 \%$ for the $1 \mathrm{mg} /$ day dose and $1.4 \% v$ $0 \%$ for the $0.5 \mathrm{mg} /$ day dose). The majority of patients in both treatment groups experienced at least one treatment-emergent $\mathrm{AE}$ (Table 3). A greater proportion of patients in the tasquinimod group discontinued treatment because of AEs (17.7\% $v 10.2 \%$ ), mainly as a result of decreased appetite, fatigue, asthenia, or nausea. 


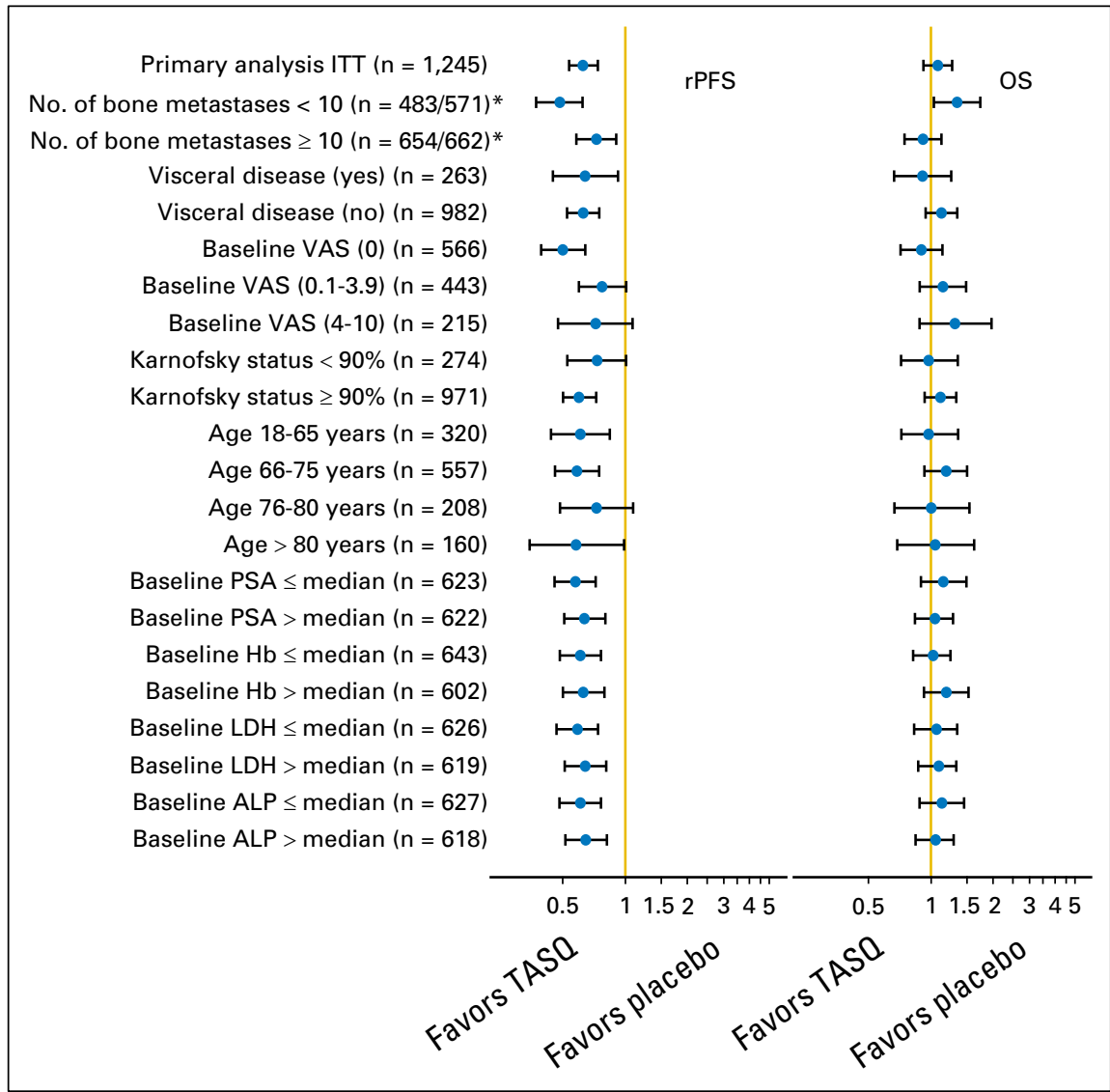

Fig 3. Radiologic progression-free survival (rPFS) and overall survival (OS) outcomes in patient subgroups. * Number of patients included in analyses of rPFS/OS. ALP, alkaline phosphatase; $\mathrm{Hb}$, hemoglobin; ITT, intent to treat; $L D H$, lactate dehydrogenase; PSA, prostate-specific antigen; TASO, tasquinimod; VAS, Visual Analog Scale.

The most common reported AEs were GI disorders $(60.2 \%$ for the tasquinimod group $v 47.9 \%$ for the placebo group), general disorders and administration site conditions (55.1\% $v 39.9 \%)$, and musculoskeletal and connective tissue disorders (48.2\% v 36.7\%). The most frequently reported AEs are summarized in Table 3.
A total of 229 patients $(27.6 \%)$ in the tasquinimod group and 97 patients $(23.6 \%)$ in the placebo group experienced at least one serious $\mathrm{AE}$, the most common being renal and urinary disorders $(7.3 \% \vee 7.3 \%)$, infections and infestations $(5.1 \% \vee 4.1 \%)$, and blood and lymphatic system disorders (4.3\% v 4.1\%).

\begin{tabular}{|c|c|c|c|c|c|c|c|}
\hline \multirow[b]{2}{*}{ Progression } & \multicolumn{2}{|c|}{$\begin{array}{l}\text { Tasquinimod } \\
\quad(\mathrm{n}=832)\end{array}$} & \multicolumn{2}{|c|}{$\begin{array}{l}\text { Placebo } \\
(\mathrm{n}=413)\end{array}$} & \multirow[b]{2}{*}{$\mathrm{HR}$} & \multirow[b]{2}{*}{$95 \% \mathrm{Cl}$} & \multirow[b]{2}{*}{$P$} \\
\hline & Median (months) & $95 \% \mathrm{Cl}$ & Median (months) & $95 \% \mathrm{Cl}$ & & & \\
\hline \multicolumn{8}{|l|}{ Radiologic progression } \\
\hline Local & 8.0 & 5.8 to 8.3 & 4.6 & 3.2 to 5.5 & 0.683 & 0.591 to 0.789 & $<.001$ \\
\hline Central & 8.4 & 8.1 to 9.2 & 5.5 & 4.5 to 5.6 & 0.628 & 0.534 to 0.739 & $<.001$ \\
\hline \multicolumn{8}{|l|}{ Soft tissue progression (RECIST 1.1) } \\
\hline Local & 16.6 & 13.6 to 19.4 & 8.3 & 5.9 to 10.9 & 0.586 & 0.483 to 0.711 & $<.001$ \\
\hline Central & 16.6 & 14.6 to 20.5 & 11.1 & 8.2 to 14.0 & 0.621 & 0.504 to 0.765 & $<.001$ \\
\hline Symptomatic progression* & 9.5 & 7.8 to 11.1 & 11.9 & 8.9 to 14.1 & 1.171 & 1.014 to 1.353 & .031 \\
\hline Initiation of salvage therapy† & 11.4 & 9.1 to 13.1 & 8.1 & 6.7 to 9.7 & 0.778 & 0.667 to 0.907 & .001 \\
\hline Initiation of further cytotoxic therapy & 25.8 & 22.1 to 35.9 & 16.0 & 13.6 to 23.2 & 0.809 & 0.675 to 0.969 & .021 \\
\hline Opiate use for cancer pain & 29.5 & 25.1 to $N R$ & 35.9 & 29.4 to $N R$ & 1.328 & 1.060 to 1.664 & .013 \\
\hline FACT-P deterioration (criterion 1$) \ddagger$ & 3.0 & 2.9 to 3.3 & 5.8 & 5.6 to 6.5 & 1.447 & 1.265 to 1.655 & $<.001$ \\
\hline PSA progression & 2.9 & 2.8 to 2.9 & 2.8 & 2.8 to 2.8 & 0.826 & 0.723 to 0.945 & .003 \\
\hline \multicolumn{8}{|c|}{$\begin{array}{l}\text { NOTE. Time to skeletal-related events and time to symptomatic progression as a result of skeletal-related events could not be calculated because of the low number of } \\
\text { events. } \\
\text { Abbreviations: FACT-P, Functional Assessment of Cancer Therapy-Prostate; HR, hazard ratio; NR, not reached; PSA, prostate-specific antigen. } \\
\text { *Including death as a result of prostate cancer. } \\
\text { tIncluding radionuclide, chemotherapy, or radiation therapy. } \\
\text { fDeterioration event was classified as the first of (1) death as a result of prostate cancer, (2) significant and meaningful decline in FACT-P total score, or (3) disease } \\
\text { progression, defined as radiologic progression and a missing FACT-P at the same scheduled visit. }\end{array}$} \\
\hline
\end{tabular}




\begin{tabular}{|c|c|c|c|c|c|c|c|c|}
\hline \multirow[b]{3}{*}{$\mathrm{AE}$} & \multicolumn{4}{|c|}{$\begin{array}{l}\text { Tasquinimod } \\
(n=830)\end{array}$} & \multicolumn{4}{|c|}{$\begin{array}{l}\text { Placebo } \\
(n=411)\end{array}$} \\
\hline & \multicolumn{2}{|c|}{ All Grades } & \multicolumn{2}{|c|}{$\begin{array}{c}\text { Grades } \\
3 \text { to } 5 \\
\end{array}$} & \multicolumn{2}{|c|}{ All Grades } & \multicolumn{2}{|c|}{$\begin{array}{l}\text { Grades } \\
3 \text { to } 5\end{array}$} \\
\hline & No. & $\%$ & No. & $\%$ & No. & $\%$ & No. & $\%$ \\
\hline All AEs & 791 & 95.3 & 355 & 42.8 & 381 & 92.7 & 138 & 33.6 \\
\hline Cancer pain & 264 & 31.8 & 27 & 3.3 & 129 & 31.4 & 10 & 2.4 \\
\hline Decreased appetite & 250 & 30.1 & 15 & 1.8 & 67 & 16.3 & 4 & 1.0 \\
\hline Nausea & 222 & 26.7 & 7 & 0.8 & 89 & 21.7 & 3 & 0.7 \\
\hline Fatigue & 217 & 26.1 & 28 & 3.4 & 72 & 17.5 & 9 & 2.2 \\
\hline Constipation & 194 & 23.4 & 8 & 1.0 & 67 & 16.3 & 2 & 0.5 \\
\hline Anemia & 179 & 21.6 & 69 & 8.3 & 67 & 16.3 & 31 & 7.5 \\
\hline Asthenia & 140 & 16.9 & 23 & 2.8 & 51 & 12.4 & 8 & 1.9 \\
\hline Decreased weight & 125 & 15.1 & 15 & 1.8 & 35 & 8.5 & 3 & 0.7 \\
\hline Back pain & 105 & 12.7 & 10 & 1.2 & 38 & 9.2 & 1 & 0.2 \\
\hline Pain in extremity & 104 & 12.5 & 10 & 1.2 & 31 & 7.5 & 1 & 0.2 \\
\hline Arthralgia & 101 & 12.2 & 8 & 1.0 & 52 & 12.7 & 0 & \\
\hline Diarrhea & 94 & 11.3 & 3 & 0.4 & 42 & 10.2 & 3 & 0.7 \\
\hline Insomnia & 87 & 10.5 & 2 & 0.2 & 30 & 7.3 & 0 & \\
\hline Vomiting & 87 & 10.5 & 3 & 0.4 & 28 & 6.8 & 3 & 0.7 \\
\hline Peripheral edema & 85 & 10.2 & 3 & 0.4 & 28 & 6.8 & 1 & 0.2 \\
\hline
\end{tabular}

Abbreviation: $A E$, adverse event.

The incidence of vascular disorders was similar for the tasquinimod and placebo groups $(12.4 \% v 13.1 \%)$, as was the incidence of deep vein thrombosis $(0.7 \% \quad v 1.5 \%)$. Cardiac disorders were more frequent with tasquinimod (all grades, $10 \% \vee 6.8 \%$; grades 3 to $5,3.4 \% v 1.6 \%$; serious AEs, $3.9 \% v$ $1.9 \%)$. The frequencies of specific cardiac events for tasquinimod and placebo groups, respectively, were atrial fibrillation $(2.8 \% v 0.7 \%)$, angina pectoris $(1.2 \% v 0.7 \%)$, cardiac failure $(1.2 \% \vee 0.2 \%)$, pericardial effusion $(0.8 \% \vee 0 \%)$, pericarditis $(0.4 \% v 0 \%)$, coronary artery disease $(0.4 \% v 0 \%)$, and myocardial infarction $(0.5 \% v 0.2 \%)$. The incidence of death as a result of AEs was similar between the groups: 27 patients $(3.3 \%)$ in the tasquinimod group and 15 patients $(3.6 \%)$ in the placebo group. There were four $(0.5 \%)$ cardiac AE-related deaths in the tasquinimod group and one $(0.2 \%)$ in the placebo group.

\section{DISCUSSION}

Tasquinimod was shown in a randomized phase II study to improve PFS in patients with mCRPC, and it was further indicated that this effect might be associated with an OS benefit. ${ }^{15,16}$ The primary objective of this phase III study was to confirm the phase II findings, and therefore a similar design was used with rPFS as the primary end point. However, the study was designed with sufficient statistical power to detect a potential OS benefit, and OS was the main secondary end point. The results showed that rPFS was significantly delayed by tasquinimod $(36 \%$ reduced risk of radiographic progression or death $v$ placebo, by central review; HR, $0.64)$, thereby confirming the phase II findings. There was good agreement between independent radiologists and local investigator assessment, suggesting that rPFS can be reliably ascertained, and recent data suggest that delays in rPFS may be associated with prolonged survival. $^{22}$

However, the significant rPFS benefit with tasquinimod did not translate into improved survival over time. Subgroup analyses demonstrated consistent results for rPFS and OS and did not highlight any clear heterogeneity for an OS benefit among any of the subgroups. Tasquinimod seemed to provide clinical benefit over placebo with respect to a number of other objective radiologybased measures as well as for time to PSA progression. Time to initiation of further cytotoxic therapy was prolonged by 9.8 months likely because of the delayed progression with tasquinimod treatment. However, this was not the case for more subjective outcomes such as time to opiate use for cancer pain, time to tumorrelated pain progression, and time to QoL deterioration, all of which were better in the placebo group. The most common AEs over-represented in the tasquinimod group included the types of events that are also commonly seen as signs of cancer progression and general health deterioration and thus may have contributed to the unfavorable outcome of symptomatically assessed end points.

Assessing clinical benefit in $\mathrm{MCRPC}$ is challenging, given the heterogeneous nature of the disease and differential effects of subsequent therapy on traditional end points, such as OS and postprogression time-to-event end points. ${ }^{23}$ PCWG2 guidelines on defining disease progression ${ }^{7}$ have been adopted as the standard primary efficacy measure in most recent clinical trials in mCRPC, and there is widespread interest in the use of PCWG2-defined rPFS as a surrogate end point of survival benefit. A recent analysis of the phase III COU-AA-302 (Abiraterone Acetate in Asymptomatic or Mildly Symptomatic Patients With Metastatic Castration-Resistant Prostate Cancer) trial demonstrated a significant correlation between rPFS and OS. ${ }^{22}$ However, the lack of correlation between rPFS and OS in this study and in other phase III studies in mCRPC $^{24-26}$ illustrates that significant improvements in rPFS may not always translate into longer-term survival benefit.

Among several possible explanations for the lack of OS benefit in this study, one contributory factor may be the availability of more effective salvage therapies that prolong OS treatment after the study, ${ }^{27}$ many of which were not widely available at the time of the phase II study. The current availability of such agents (eg, abiraterone and enzalutamide) may have had an impact on the course of disease because patients in the placebo group gained access before those in the tasquinimod group on account of their earlier withdrawal from study treatment. Indeed, post-treatment use of abiraterone and enzalutamide was more common among patients in the placebo group. Furthermore, baseline characteristics suggest a more aggressive cancer population in the tasquinimod arm as indicated by an imbalance in median time since diagnosis and baseline Visual Analog Scale score for tumor-related pain. It may also be that the survival results were influenced by a combination of the relatively modest effect on rPFS and other confounding factors, suggesting that tasquinimod may not have sufficient efficacy as a single agent to have an impact on long-term OS.

Further study of predictive biomarkers of tasquinimod efficacy may be warranted to determine whether certain subgroups will derive an OS advantage. Data from the phase II trial suggested that men with low baseline thrombospondin-1 levels derived the greatest benefit from tasquinimod. ${ }^{16}$ Because tasquinimod is 
known to increase this antiangiogenic marker in preclinical tumor models, ${ }^{28}$ there may be a mechanistic basis for further examination of predictive biomarkers identified in this study. Preclinical evidence also suggests that tasquinimod has immunomodulatory activity, shown as an inhibitory effect on myeloid-derived suppressive cells and M2-polarized tumor-associated macrophages. ${ }^{13}$ Identification of a potential immunologic biomarker will help with patient selection and determination of the most rational combination strategy for developing S100A9 inhibitors.

The tolerability of tasquinimod was good overall, and the vast majority of patients were able to escalate to the maximum 1-mg/day dose according to the predefined schedule. Dose interruptions or reductions were infrequent, and the overall safety profile was consistent with that observed in the phase II study. Tasquinimod was associated with a higher rate of withdrawals as a result of AEs. GI and musculoskeletal disorders occurred at a slightly higher frequency with tasquinimod, as seen in the phase II study. The overall incidence of cardiovascular events was low but, as observed previously, ${ }^{15,16}$ was slightly higher with tasquinimod. This higher rate of cardiovascular events may have contributed to the lack of survival benefit due to early drug discontinuation. However, treatment-related deaths were not increased with tasquinimod, suggesting lack of efficacy rather than toxicity as the main contributing factor.

In conclusion, this phase III study confirmed that tasquinimod improved rPFS in patients with mCRPC compared with placebo. This benefit did not translate into an improvement in OS. The tolerability profile of tasquinimod was consistent with that in previous studies. On the basis of the lack of OS benefit observed in this study, further clinical development of tasquinimod in this patient population was not pursued.

\section{AUTHORS' DISCLOSURES OF POTENTIAL CONFLICTS OF INTEREST}

Disclosures provided by the authors are available with this article at www.jco.org.

\section{AUTHOR CONTRIBUTIONS}

Conception and design: Cora Sternberg, Andrew Armstrong, Roberto Pili, Thore Nederman, Helen Tuvesson, Michael Carducci

Provision of study materials or patients: Andrew Armstrong, Siobhan Ng, Robert Huddart, Neeraj Agarwal, Rémy Delva, Nicholas James, Thomas Hutson, Enrique Gallardo, Thore Nederman, Helen Tuvesson, Michael Carducci

Collection and assembly of data: Cora Sternberg, Andrew Armstrong, Roberto Pili, Robert Huddart, Neeraj Agarwal, Denis Khvorostenko, Olexiy Lyulko, Arija Brize, Nicholas Vogelzang, Rémy Delva, Mihai Harza, Anastasios Thanos, Nicholas James, Patrick Werbrouck, Martin Bögemann, Thomas Hutson, Piotr Milecki, Enrique Gallardo, Gilberto Schwartsmann, Michael Carducci

Data analysis and interpretation: Cora Sternberg, Andrew Armstrong, Roberto Pili, Siobhan Ng, Robert Huddart, Neeraj Agarwal, Nicholas James, Thomas Hutson, Piotr Milecki, Simon Chowdhury, Jean-Christophe Pouget, Frédérique Baton, Thore Nederman, Helen Tuvesson, Michael Carducci

Manuscript writing: All authors

Final approval of manuscript: All authors

\section{REFERENCES}

1. Beer TM, Armstrong AJ, Rathkopf DE, et al: Enzalutamide in metastatic prostate cancer before chemotherapy. N Engl J Med 371:424-433, 2014

2. de Bono JS, Oudard S, Ozguroglu M, et al: Prednisone plus cabazitaxel or mitoxantrone for metastatic castration-resistant prostate cancer progressing after docetaxel treatment: A randomised open-label trial. Lancet 376:1147-1154, 2010

3. de Bono JS, Logothetis CJ, Molina A, et al: Abiraterone and increased survival in metastatic prostate cancer. N Engl J Med 364:1995-2005, 2011

4. Kantoff PW, Higano CS, Shore ND, et al: Sipuleucel-T immunotherapy for castration-resistant prostate cancer. N Engl J Med 363:411-422, 2010

5. Parker C, Nilsson S, Heinrich D, et al: Alpha emitter radium-223 and survival in metastatic prostate cancer. N Engl J Med 369:213-223, 2013

6. Ryan CJ, Smith MR, de Bono JS, et al: Abiraterone in metastatic prostate cancer without previous chemotherapy. N Engl J Med 368:138-148, 2013

7. Scher HI, Halabi S, Tannock I, et al: Design and end points of clinical trials for patients with progressive prostate cancer and castrate levels of testosterone: Recommendations of the Prostate Cancer Clinical Trials Working Group. J Clin Oncol 26: 1148-1159, 2008

8. Sounni NE, Noel A: Targeting the tumor microenvironment for cancer therapy. Clin Chem 59: 85-93, 2013
9. Ganguly SS, Li X, Miranti CK: The host microenvironment influences prostate cancer invasion, systemic spread, bone colonization, and osteoblastic metastasis. Front Oncol 4:364, 2014

10. Clarke JM, Armstrong AJ: Novel therapies for the treatment of advanced prostate cancer. Curr Treat Options Oncol 14:109-126, 2013

11. Gupta N, Al Ustwani $O$, Shen L, et al: Mechanism of action and clinical activity of tasquinimod in castrate-resistant prostate cancer. Onco Targets Ther 7:223-234, 2014

12. Raymond E, Dalgleish A, Damber JE, et al: Mechanisms of action of tasquinimod on the tumour microenvironment. Cancer Chemother Pharmacol 73:1-8, 2014

13. Shen $L$, Sundstedt $A$, Ciesielski $M$, et al: Tasquinimod modulates suppressive myeloid cells and enhances cancer immunotherapies in murine models. Cancer Immunol Res 3:136-148, 2015

14. Isaacs JT, Antony L, Dalrymple SL, et al: Tasquinimod is an allosteric modulator of HDAC4 survival signaling within the compromised cancer microenvironment. Cancer Res 73:1386-1399, 2013

15. Pili R, Häggman $M$, Stadler WM, et al: Phase II randomized, double-blind, placebo-controlled study of tasquinimod in men with minimally symptomatic metastatic castrate-resistant prostate cancer. J Clin Oncol 29:4022-4028, 2011

16. Armstrong AJ, Häggman M, Stadler WM, et al: Long-term survival and biomarker correlates of tasquinimod efficacy in a multicenter randomized study of men with minimally symptomatic metastatic castration-resistant prostate cancer. Clin Cancer Res 19:6891-6901, 2013
17. Scher HI, Fizazi $K$, Saad $F$, et al: Increased survival with enzalutamide in prostate cancer after chemotherapy. N Engl J Med 367:1187-1197, 2012

18. Bratt $O$, Häggman $M$, Ahlgren $G$, et al: Openlabel, clinical phase I studies of tasquinimod in patients with castration-resistant prostate cancer. $\mathrm{Br} \mathrm{J}$ Cancer 101:1233-1240, 2009

19. Eisenhauer EA, Therasse $P$, Bogaerts J, et al: New response evaluation criteria in solid tumours: Revised RECIST guideline (version 1.1). Eur J Cancer 45:228-247, 2009

20. Lan KKG, Demets DL: Discrete sequential boundaries for clinical trials. Biometrika 70:659-663, 1983

21. Brookmeyer $R$, Crowley $\mathrm{J}$ : A confidence interval for the median survival time. Biometrics 38:29-41, 1982

22. Morris MJ, Molina A, Small EJ, et al: Radiographic progression-free survival as a response biomarker in metastatic castration-resistant prostate cancer: COU-AA302 results. J Clin Oncol 33:1356-1363, 2015

23. Armstrong AJ, Halabi S: Making progress on progression in metastatic prostate cancer. J Clin Oncol 33:1322-1324, 2015

24. Fizazi $K$, Jones $R$, Oudard $S$, et al: Phase III, randomized, double-blind, multicenter trial comparing orteronel (TAK-700) plus prednisone with placebo plus prednisone in patients with metastatic castration-resistant prostate cancer that has progressed during or after docetaxel-based therapy: ELM-PC 5. J Clin Oncol 33:723-731, 2015

25. Kelly WK, Halabi S, Carducci M, et al: Randomized, double-blind, placebo-controlled phase III trial comparing docetaxel and prednisone with or without bevacizumab in men with metastatic castration-resistant prostate cancer: CALGB 90401. J Clin Oncol 30:1534-1540, 2012 
26. Michaelson MD, Oudard $S, O u Y C$, et al: Randomized, placebo-controlled, phase III trial of sunitinib plus prednisone versus prednisone alone in progressive, metastatic, castration-resistant prostate cancer. J Clin Oncol 32:76-82, 2014
27. Crawford ED, Higano CS, Shore ND, et al: Treating patients with metastatic castration resistant prostate cancer: A comprehensive review of available therapies. J Urol 194:1537-1547, 2015
28. Olsson A, Björk A, Vallon-Christersson J, et al: Tasquinimod (ABR-215050), a quinoline-3-carboxamide anti-angiogenic agent, modulates the expression of thrombospondin-1 in human prostate tumors. Mol Cancer 9:107, 2010

\section{Affiliations}

Cora Sternberg, San Camillo Forlanini Hospitals, Rome, Italy; Andrew Armstrong, Duke Cancer Institute, Duke University, Durham, NC; Roberto Pili, Indiana University School of Medicine, Indianapolis, IN; Siobhan Ng, St John of God Medical Centre, Subiaco, Western Australia, Australia; Robert Huddart, Royal Marsden Hospital, Sutton; Nicholas James, Queen Elizabeth Hospital, Birmingham; Simon Chowdhury, Guy's Hospital and Sarah Cannon Research UK, London, United Kingdom; Neeraj Agarwal, University of Utah, Salt Lake City, UT; Denis Khvorostenko, Leningrad Regional Oncology Dispensary, St Petersburg, Russia; Olexiy Lyulko, Zaporizhzhya Regional Clinical Hospital, Zaporizhzhya, Ukraine; Arija Brize, Riga Eastern Clinical University Hospital, Riga, Latvia; Nicholas Vogelzang, Comprehensive Cancer Centers of Nevada, Las Vegas, NV; Rémy Delva, Centre Régional de Lutte Contre le Cancer Paul Papin, Angers; Jean-Christophe Pouget and Frédérique Baton, Ipsen Innovation, Les Ulis, France; Mihai Harza, Fundeni Clinical Institute, Bucharest, Romania; Anastasios Thanos, Agios Savas Anticancer Oncology Hospital of Athens, Athens, Greece; Patrick Werbrouck, Algemeen Ziekenhuis Groeninge, Kortrijk, Belgium; Martin Bögemann, Universitätsklinikum Münster, Münster, Germany; Thomas Hutson, Texas Oncology, Dallas, TX; Piotr Milecki, Poznan University of Medical Sciences, Poznan, Poland; Enrique Gallardo, Corporació Sanitaria Parc Taulí, Sabadell, Spain; Gilberto Schwartsmann, Hospital De Clinicas De Porto Alegre, Porto Alegre, Brazil; Thore Nederman and Helen Tuvesson, Active Biotech, Lund, Sweden; and Michael Carducci, Sidney Kimmel Comprehensive Cancer Center at Johns Hopkins University, Baltimore, MD.

\section{Participate in ASCO's Practice Guidelines Implementation Network and Influence Cancer Care}

ASCO members are invited to serve in the society's Practice Guidelines Implementation Network (PGIN), a network of oncology professionals who raise awareness of ASCO's evidence-based recommendations on cancer care.

Participation in PGIN provides an opportunity for members to positively influence the way that clinical oncology is delivered now and in the future. PGIN members have the opportunity to:

- Participate in Guideline Panels and Advisory Groups

- Aid in developing and reviewing Guidelines and Guideline Clinical Tools and Resources

- Serve as an "ambassador" to state societies

- Better implement Guidelines

To learn how you can participate, visit asco.org/guidelines, or contact PGIN@asco.org. 
Randomized, Double-Blind, Placebo-Controlled Phase III Study of Tasquinimod in Men With Metastatic Castration-Resistant Prostate Cancer

The following represents disclosure information provided by authors of this manuscript. All relationships are considered compensated. Relationships are self-held unless noted. I = Immediate Family Member, Inst = My Institution. Relationships may not relate to the subject matter of this manuscript. For more information about ASCO's conflict of interest policy, please refer to www.asco.org/rwc or jco.ascopubs.org/site/ifc.

\section{Cora Sternberg}

Honoraria: Pfizer, Novartis, Janssen Pharmaceuticals, Sanofi, GlaxoSmithKline

Consulting or Advisory Role: Bristol-Myers Squibb, Bayer HealthCare Pharmaceuticals, Astellas Pharma, Eisai

Research Funding: Sanofi (Inst), Bayer (Inst), Pfizer (Inst), Exelixis (Inst), Astellas Pharma (Inst), Medivation (Inst), Active Biotech (Inst),

Genentech (Inst)

\section{Andrew Armstrong}

Honoraria: Dendreon, Sanofi

Consulting or Advisory Role: Bayer HealthCare Pharmaceuticals, Sanofi, Novartis, Dendreon, Medivation, Janssen Biotech

Speakers' Bureau: Dendreon, Sanofi

Research Funding: Dendreon (Inst), Sanofi (Inst), Bayer HealthCare Pharmaceuticals (Inst), Pfizer (Inst), Novartis (Inst), Bristol-Myers Squibb (Inst), KangLaiTe (Inst), Janssen Oncology (Inst), Medivation (Inst), Astellas Pharma (Inst), ImClone Systems (Inst), Active Biotech (Inst) Patents, Royalties, Other Intellectual Property: Circulating tumor cell novel capture technology (Inst)

Travel, Accommodations, Expenses: Dendreon, Medivation, Janssen Biotech

Roberto Pili

Consulting or Advisory Role: Ipsen

Research Funding: Active Biotech

\section{Siobhan Ng}

Consulting or Advisory Role: Janssen-Cilag, Astellas Pharma, Pfizer,

Novartis, GlaxoSmithKline, Sanofi

Expert Testimony: Janssen-Cilag, Astellas Pharma

Travel, Accommodations, Expenses: Sanofi, Novartis, Astellas

\section{Robert Huddart}

Leadership: Cancer Centre London

Consulting or Advisory Role: Astellas Pharma, Merck Sharp \& Dohme, Janssen Oncology

Speakers' Bureau: Pierre Fabre

Research Funding: Merck Sharp \& Dohme

Travel, Accommodations, Expenses: Janssen Oncology, Merck Sharp \& Dohme

\section{Neeraj Agarwal}

Consulting or Advisory Role: Pfizer, Medivation/Astellas Pharma, Exelixis, Argos Therapeutics, Cerulean Pharma

\section{Denis Khvorostenko}

No relationship to disclose

Olexiy Lyulko

No relationship to disclose

Arija Brize

No relationship to disclose

\section{Nicholas Vogelzang}

Stock or Other Ownership: Caris Life Sciences

Honoraria: UpToDate, Endocyte

Consulting or Advisory Role: Janssen Biotech, Amgen, Cerulean Pharma, Pfizer

Speakers' Bureau: Medivation, Dendreon, Bayer AG, Sanofi,

GlaxoSmithKline, Genentech

Research Funding: PAREXEL International (Inst), Progenics

Pharmaceuticals (Inst), US Oncology (Inst), Viamet Pharmaceuticals (Inst), Endocyte (Inst), GlaxoSmithKline (Inst)

Travel, Accommodations, Expenses: Genentech, Celgene, US Oncology, Dendreon, Novartis, Pfizer, Bayer AG, Exelixis

Rémy Delva

No relationship to disclose

Mihai Harza

No relationship to disclose

Anastasios Thanos

No relationship to disclose

Nicholas James

Honoraria: Sanofi, Bayer HealthCare Pharmaceuticals, OncoGenex, Janssen Pharmaceuticals, Astellas Pharma, Pierre Fabre

Consulting or Advisory Role: Sanofi, Bayer HealthCare Pharmaceuticals, Merck, Astellas Pharma, Janssen Pharmaceuticals

Speakers' Bureau: Pierre Fabre, Ferring Pharmaceuticals, Sanofi, Astellas Pharma, Janssen Pharmaceuticals, Ipsen

Research Funding: Janssen Pharmaceuticals (Inst), Astellas Pharma (Inst), Pfizer (Inst), Sanofi (Inst), Novartis (Inst), Active Biotech (Inst), Bayer HealthCare Pharmaceuticals (Inst), Merck (Inst), Genentech (Inst)

\section{Patrick Werbrouck}

No relationship to disclose

\section{Martin Bögemann}

Honoraria: Janssen-Cilag, Astellas Pharma, Amgen, Sanofi, Pfizer, BristolMyers Squibb

Consulting or Advisory Role: Janssen-Cilag, Astellas Pharma, Amgen, Sanofi, Pfizer, Bristol-Myers Squibb

Travel, Accommodations, Expenses: Bayer Vital GmbH, Janssen-Cilag, Astellas Pharma, TEVA Pharmaceuticals

\section{Thomas Hutson}

Employment: Texas Oncology

Honoraria: Bayer/Onyx, Pfizer, Medivation, Novartis, Johnson \& Johnson, GlaxoSmithKline, Dendreon

Consulting or Advisory Role: Bayer/Onyx, Pfizer, Novartis, Astellas Pharma, GlaxoSmithKline

Speakers' Bureau: Dendreon, Pfizer, GlaxoSmithKline, Bayer/Onyx, Johnson \& Johnson, Medivation

Research Funding: Pfizer (Inst), GlaxoSmithKline (Inst), Johnson \& Johnson (Inst), Medivation (Inst)

\section{Piotr Milecki}

Honoraria: Astellas Pharma, Ipsen, AstraZeneca

Travel, Accommodations, Expenses: Astellas Pharma, Ipsen

Pharmaceuticals 


\section{Simon Chowdhury}

Honoraria: Pfizer, Novartis, Janssen-Cilag, Astellas Pharma

Consulting or Advisory Role: Novartis, Sanofi, Johnson \& Johnson, Astellas Pharma, Pfizer, Bayer AG

Speakers' Bureau: Astellas Pharma, Sanofi, Johnson \& Johnson, Bayer AG Research Funding: Sanofi

Travel, Accommodations, Expenses: Astellas Pharma, Johnson \& Johnson, Bayer

\section{Enrique Gallardo}

Honoraria: Novartis, Pfizer, Ipsen

Consulting or Advisory Role: Pfizer, GlaxoSmithKline, Novartis, Astellas Pharma, Janssen Oncology, Bayer Schering Pharma

Speakers' Bureau: Pfizer, Novartis, GlaxoSmithKline, Astellas Pharma, LEO Pharma, Sanofi

Travel, Accommodations, Expenses: Pfizer, Novartis, Astellas Pharma, Janssen Oncology, Pierre Fabre, Sanofi

\section{Gilberto Schwartsmann}

No relationship to disclose
Jean-Christophe Pouget

Employment: Ipsen

Frédérique Baton

Employment: Ipsen

Stock or Other Ownership: Ipsen

Thore Nederman

Employment: Active Biotech

Stock or Other Ownership: Active Biotech

Helen Tuvesson

Employment: Active Biotech

Leadership: Active Biotech

Stock or Other Ownership: Active Biotech

Michael Carducci

Consulting or Advisory Role: Medivation, Astellas Pharma, AstraZeneca, Clovis Oncology, Merck 


\section{Acknowledgment}

We thank Neil Anderson from Adelphi Communications who provided medical writing support that was funded by Ipsen.

\section{Appendix}

\begin{tabular}{|c|c|}
\hline Site & Principal Investigator \\
\hline \multicolumn{2}{|l|}{ Australia } \\
\hline The Tweed Hospital, Tweed Heads & Ehtesham Abdi, MBBS \\
\hline Coffs Harbor Health Campus, Coffs Harbor & Karen Briscoe, MBBS \\
\hline Australian Prostate Cancer Research Centre, Richmond & Anthony Costello, MD, MBBS \\
\hline St John of God Subiaco Hospital, Subiaco & Siobhan Ng, MBBS \\
\hline St Vincent's Hospital, Darlinghurst & Richard Epstein, MD, PhD, MBBS \\
\hline Royal Prince Alfred Hospital, Camperdown & Lisa Horvath, MBBS, PhD \\
\hline \multicolumn{2}{|l|}{ India } \\
\hline Jehangir Clinical Development Centre, Pune & Bhalchandra Kashyapi, MBBS, MCh, MS \\
\hline \multicolumn{2}{|l|}{ New Zealand } \\
\hline Tauranga Urology Research, Tauranga & Peter Gilling, MD \\
\hline Canterbury Urology Research Trust, Christchurch & Frank Kueppers, MD, PhD \\
\hline $\begin{array}{l}\text { Roundhay Medical Centre and Nelson Public Hospital, Nelson; Wairau Public } \\
\text { Hospital, Blenheim }\end{array}$ & Patrick Meffan, MBChB, FRACS \\
\hline Palmerston North Hospital, Palmerston North & Quinten King, MBBCh, FRCS \\
\hline \multicolumn{2}{|l|}{ Korea } \\
\hline Gangnam Severance Hospital, Seoul & Byung Ha Chung, MD, PhD \\
\hline Chonnam National University Hospital, Gwangju & Taek Won Kang, MD, PhD \\
\hline Seoul St Mary's Hospital, Seoul & Sae Woong Kim, MD, PhD \\
\hline Asan Medical Center, Seoul & Choung-Soo Kim, MD \\
\hline Severance Hospital, Seoul & Sung Joon Hong, MD, PhD, MS \\
\hline Samsung Medical Center, Seoul & Hyun Moo Lee, MD, PhD \\
\hline \multicolumn{2}{|l|}{ Taiwan } \\
\hline Chang Gung Medical Foundation, Taoyuan & Cheng-Keng Chuang, MD \\
\hline Taichung Veterans General Hospital, Taichung & Yen-Chuan Ou, MD, PhD \\
\hline National Taiwan University Hospital, Taipei & Yu-Chieh Tsai, MD \\
\hline Kaohsiung Veterans General Hospital, Kaohsiung & Tong-Lin Wu, MD, EMBA \\
\hline \multicolumn{2}{|l|}{ China } \\
\hline Urology Surgery Department, Beijing & Lijun Chen, MD \\
\hline Fudan University Shanghai Cancer Center, Shanghai & Dingwei $Y e, M D$ \\
\hline Chengdu Military General Hospital, Chengdu & Liang Wang, MD \\
\hline Urology Surgery Department, Shantou & Junhong Zheng, MD \\
\hline Huashan Hospital, Shanghai & Qiang Ding, MD \\
\hline Zhongnan Hospital of Wuhan University, Wuhan & Fuxiang Zhou, MD \\
\hline \multicolumn{2}{|l|}{ Argentina } \\
\hline Centro Oncológico "Ágave," Santa Fe & Natalia Broglia Sicco, MD \\
\hline Centro de Diagnóstico Urológico, Buenos Aires & Luis Fernando Montes de Oca, MD \\
\hline Centro Oncológico Fundacion Koria, St Rosa & Pablo Picon, MD \\
\hline Hospital Italiano de Buenos Aires, Buenos Aires & María Pallotta, MD \\
\hline \multicolumn{2}{|l|}{ Brazil } \\
\hline Hospital Evangelico de Cachoeiro de Itapemirim, Cachoeiro de Itapemirim & Sabina Aleixo, MD \\
\hline $\begin{array}{l}\text { Granbery Juiz de Fora Hospital Universitario da Universidade Federal de Juiz } \\
\text { de Fora Avenue Eugenio do Nascimento, Juiz de Fora }\end{array}$ & Christiane Alves, MD \\
\hline Rio de Janeiro Hospital St Maria Madalena Estrada do Dende, Rio de Janeiro & lane Cardoso, MD \\
\hline $\begin{array}{l}\text { Natal Liga Norte Riograndense Contra o Cancer Unidade I Hospital Luiz } \\
\text { Antonio, Natal }\end{array}$ & Danielli Matias, MD \\
\hline Florianopolis Hospital, Bala Sul Medical Center, Florianopolis & Yeni Neron, MD \\
\hline Salvador Hospital da Bahia, Salvador & José Nogueira, MD \\
\hline Sao Paulo Centro de Pesquisa Clinical, Sao Paulo & Roberto Rocha, MD \\
\hline Centro Oncologico Mogi das Cruzez, Sao Paulo & Daniel Grabarz, MD \\
\hline Passo Fundo Hospital Sao Vicente de Paulo, Passo Fundo & Luis Schlittler, MD \\
\hline Hospital de Clinicas de Porto Alegre, Porto Alegre & Gilberto Schwartsmann, MD \\
\hline $\begin{array}{l}\text { Rio Sul Centro de Atencao e Saude Humana, Rio de Janeiro Hospital, Rio de } \\
\text { Janeiro }\end{array}$ & Leonardo Osorio, MD; Heloisa M. Resende, MD \\
\hline Universidade Estadual Paulista, Sao Paulo & Guareide Carelli, MD \\
\hline $\begin{array}{r}\text { Liga Paranaense de Combate ao Cancer, Hospital Erasto Gaertner, Curitba } \\
\text { (continued on following page) }\end{array}$ & Flavio Tomasich, MD \\
\hline
\end{tabular}


Table A1. Phase III Study Sites (241) in 37 Countries (continued)

Site

Principal Investigator

Chile

Hospital Clinico Vina de Mar Limache, Vina de Mar

Clinicia Alemana de Temuco, Temuco

Uromed Ave Salvador 351, Santiago

Hospital Dipreca, Santiago

Hospital de Carabineros General Humberto Arriagada Valdivieso, Santiago

\section{Colombia}

Fundacion Clinica Valle del Lili, Cali

Fundacion St Fe de Bogota, Bogota

\section{Mexico}

Hospital Angeles Puebla, Puebla

Hospital Aranda de la Parra, Guanajuato

Christus Muguerza del Parque, Chihuahua

Hospital Angeles Culiacan, Culiacan

Consultorio Medico, Zapopan

\section{Panama}

Centro Hemato Oncologico Paitilla Consultorios Medicos Royal Center,

Panama City

Clinica Hospital San Fernando Centro Especializado, Panama City

Medical Research Center Edificio Consultotios America, Panama City

Clinica Hospital San Fernando, Panama City

Peru

Instituto Régional de Enfermedades Neoplasicas del Sur Ave de la Salud

Arequipa, Arequipa

Hospital Nacional Carlos Alberto Seguin Escobedo Calle Peral y Ayacucho, Arequipa

Belgium

Centre Hospitalier Universitaire Sart Tilman, Liege

Algemeen Ziekenhuis Groeninge Burgemeester, Kortijk

Erasme Hospital, Université Libre de Bruxelles, Brussels

Algemeen Ziekenhuis Maria Middelares, Gent

Bulgaria

Hospital for Treatment of Oncology Disease, Sofia

Oncology Center Plovdiv, Plovdiv

Hospital Oncology Disease Medical Oncotherapy and Palliative Care Base II,

Varna

University Multiprofile Hospital Chemotherapy Department, Pleven

\section{Czech Republic}

Fakultni Nemocnice v Motole, Urology Clinic, Prague

Urocentrum Praha, Prague

Krajska Zdravotni - Masarykova Nemocnice, Clinic of Urology and Robotic Surgery, Usti nad Labem

Nemocnice Novy Jicin, Urology Department, Novy Jicin

Fakultni Nemocnice Olomouc, Urology Clinic, Olomouc

Estonia

Tartu University Hospital, Tartu

\section{France}

Central Hospital Cannes, Cannes

Beau Soleil Clinic, Montpellier

Foch Hospital, Suresnes

Regional Center de Lutte, Angers

Centre Hospital Lyon-Sud, Pierre-Benite

Centre Régional de Lutte Contre le Cancer Val d'Aurelle, Montpellier

Centre Hospitalier Universitaire Rennes Hospital Pontchaillou, Rennes

Curie Institute, Paris

Hopital Saint-Louis Service d'Oncologie, Paris

Centre Hospitalier Universitaire La Timone Adultes-Service d'Oncologie

Medicale, Marseille

\section{Germany}

Eberhard-Karls University Tübingen, Clinic for Urology, Tübingen

Urologic Study Office, Nurtingen

University Hospital Münster, Urology, Münster

Hospitals Nordoberpfalz, Urology, Weiden

University Hospital Gießen and Marburg, Clinic for Urology and Pediatric

Urology, Marburg

University Hospital Cologne, Clinic for Urology, Cologne

University Hospital Munich, Clinic for Urology, Munich
Alejandro Acevedo Gaete, MD

Mario Gorena, MD

Anibal Salazar Huerta, MD

Luis Soto Diaz, MD

Nelson Orellana Salinas, MD

Manuel Duque Galan, MD

Carlos Vargas, MD

José Arroyo Kuribreña, MD

Marco Badillo Santoyo, MD

Roberto Hidalgo-Silva, MD

Gustavo Gaxiola Meza, MD

Jose Rodriguez Rivera, MD

Juan Bares Weeden, MD

Javier Del Rosario Gibbs, MD

Roberto Lopez Sanchez, MD

Alejandro Manduley, MD

Ernesto Vargas Quezada, MD

Hernan Moron Escobar, MD

Brieuc Sautois, MD

Patrick Werbrouck, MD

Thierry Roumeguère, MD

Filip Ameye, MD

Borislav Dimitrov, MD

Petar Petrov, MD

Violina Taskova, MD

Rumyana Micheva, MD

Josef Stolz, MD

Michaela Matouskova, MD

Jan Schraml, MD

Miroslav Stursa, MD

Vladimir Student, MD

Jaanus Kahu, MD

Regis Kaphan, MD

Xavier Rebillard, MD

Christine Theodore, MD

Rémy Delva, MD

Alain Ruffion, MD

David Azria, MD

Sebastien Vincendeau, MD

Philippe Beuzeboc, MD

Stéphane Culine, MD

Jean-Laurent Deville, MD

Arnulf Stenzl, MD

Susan Feyerabend, MD

Martin Bögemann, MD

Theodor Klotz, MD

Alex Hegele, MD

Sebastian Wille, MD

Phillip Nuhn, MD; Claudius Füllhase, MD; Patrick Bastian, MD 
Table A1. Phase III Study Sites (241) in 37 Countries (continued)

University Hospital Carl Gustav Carus Dresden, Dresden

Martini-Clinic at the University Hospital Hamburg-Eppendorf, Hamburg

University Hospital Mannheim, Clinic for Urology, Mannheim

\section{Greece}

Alexandra Hospital Department of Clinical Therapeutics, Athens

Athens Oncology Hospital Urology Clinic, Athens

Thessaloniki General Hospital, Thessaloniki

Patras University General Hospital, Rion Patras

\section{Israel}

Oncology Institute, The Chaim Sheba Medical Center, Tel Hashomer

The Lady Davis Carmel Medical Center, Haifa

Assaf Harofe Medical Center Oncology Department, Zerifin

Tel Aviv Sourasky Medical Center, Oncology Department, Tel Aviv

Oncology Institute Rambam Health Care Campus, Haifa

Institute of Oncology Davidoff Cancer Center, Rabin Medical Center, Tikva

Bnai Zion Medical Center, Haifa

Sharett Institute of Oncology, Hadassah University Hospital, Jerusalem

Soroka University Medical Center, Be'er Sheva

\section{Italy}

San Camillo Forlanini Hospital, Rome

Scientific Institute Romangnolo Via Piero Maroncelli, Meldola

Oncology Institute Veneto, Padova

Hospital di Lecco, Lecco

Oncologia Falck Hospital, Niguarda Ca Granda Piazzale Hospital, Milan

Azienda Ospedaliero Universitaria Giovanni Battista di Torino Molinette, Turin

Institute di Cremona, Cremona

Ospedale degli Infermi di Faenza Unità di Oncologia di Oncologia Medica,

Faenza

Hospital San Carlo Borromeo, Milan

\section{Latvia}

Riga Eastern Clinical University Hospital, Latvian Oncology Center, Riga

Private practice of Dzintra Litavniece, Liepaja

P. Stradins Clinical University Hospital, Riga

\section{Lebanon}

Middle East Institute of Health, Bsalim El Meten

American University of Beirut Medical Center, Beirut

\section{Lithuania}

Vilnius University Hospital, Vilnius

Institute of Oncology Vilnius University, Vilnius

Lithuanian University Health Sciences Kaunas Clinics, Kaunas

\section{The Netherlands}

St Elizabeth Hospital, Tilburg

Martini Ziekenhuis, Groningen

Canisius Wilhelmina Hospital, Nijmegen

Leiden University Medical Center, Leiden

Vrije Universiteit Medical Center, Amsterdam

University Medical Center St Radboud, Nijmegen

\section{Poland}

Curie Oncology Institute, Nowotworow Oncology Clinic, Warsaw

Niepubliczny Zaklad Opieki Zdrowotnej Urology Center, Myslowice

Regional Osrodek Oncology, Lodz

EuroMediCare, Wroclaw

Wojewodki Hospital Urology Clinic, Bialystok

Wielkopoiskie Oncology Center, Poznan

LexMedica Rudolfa, Wroclaw

\section{Romania}

Oncolab, Craiova

Fundeni Clinical Institute, Bucharest

Sf loan cel Nou Emergency County Hospital, Suceava

The Oncology Institute, Cluj Napoca

Opris Emergency County Hospital, Baia Mare

Oncomed SRL, Timisoara

lanuli Medical Consult SRL, Bucharest

Municipal Hospital Ploiesti, Ploiesti
Manfred Wirth, MD

Thomas Steuber, MD, PD

Christian Bolenz, MD, PD

Eleni Efstathiou, MD, PhD

Anastasios Thanos, MD

Athanassios Papathanasiou, MD

Petros Perimenis, MD

Raanan Berger, MD, PhD

Avi Stein, MD

Avishay Sella, MD

Eliahu Gez, MD

Avivit Peer, MD

Eli Rosenbaum, MD

Ofer Nativ, MD

Stephen Frank, MD

Wilmosh Mermershtain, MD

Cora Sternberg, MD

Cecilia Menna, MD

Umberto Basso, MD

Antonio Ardizzoia, MD

Salvatore Siena, MD

Libero Ciuffreda, MD

Rodolfo Passalacqua, MD

Francesco Carrozza, MD; Giorgio Cruciani, MD

Maria Locatelli, MD

Arija Brize, MD

Dzintra Litavniece, MD

Egils Vjaters, MD

Abi Gerges Dany, MD

Ali Shamseddine, MD

Feliksas Jankevicius, MD

Albertas Ulys, MD, PhD

Daimantas Milonas, MD

P. Kil, MD, PhD

L.F.A. Wymenga, MD, PhD

$H$. Vergunst, MD

A.J. Gelderblom, MD

R.J.A. van Moorselaar, MD

P.F.A. Mulders, MD

Tomasz Demkow, MD, PhD

Adam Dobrowolski, MD

Ewa Kalinka-Warzocha, MD

Rafal Kmieciak, MD

Robert Kozlowski, MD, PhD

Piotr Milecki, MD, PhD

Zenona Jablonska, MD

Dan Lungulescu, MD

Mihai Harza, MD

Doina Ganea, MD, PhD

Cristina Cebotaru, MD; Tudor Ciuleanu, MD, PhD

Dumitru Filip, MD

Cristina Oprean, MD

Carmen lanuli, MD

Gabriel Doru Ghizdavescu, MD 
Table A1. Phase III Study Sites (241) in 37 Countries (continued)

Site

Principal Investigator

\section{Russia}

Omsk Healthcare, Oncology Center, Omsk

Clinic Andros Lenina Street, St Petersburg

Leningrad Regional Oncology Center, St Petersburg

St Petersburg Healthcare City Hospital, St Petersburg

Vladimir Healthcare Oncology Center, Vladimir

Orkli, Sredniy Prospekt, St Petersburg

Federal State Institution Moscow Research Oncology Institute, Moscow

State Institution of Healthcare Sverdlovsk Regional Hospital, Ekaterinburg

Regional State Institution of Healthcare Novosibirsk Regional Oncology

Centre, Novosibirsk

\section{Slovak Republic}

Ambulatory Urology Clinic, Trecin

Cuimed, Bratislava

\section{Spain}

Hospital Clinic 1 Provincial Oncology Servico de Oncologia Medica, Barcelona

Corporacio Sanitaria Parc Tauli Hospital de Sabadell Servicio de Oncologia

Medica, Barcelona

Hospital Infanta Sofia, Madrid

Clinica Universidad de Navarra Servicio de Oncologia, Pamplona

Hospital Universitario Virgen del Rocio Servicio de Oncologia Medica Ave

Manuel Siurot, Sevilla

Hospital Clinico Universitario de Valencia Servicio de Oncologia Medica,

Valencia

Hospital Universitario Marques de Valdecilla Servicio de Oncologia Medica,

Santander

Hospital Universitario Vall D’Hebron Servicio de Oncologia-Unidad, Barcelona

Hospital de la Santa Creu, Barcelona

Hospital Universitario Fundacion Alcorcon Servicio de Oncologia Medica,

Alcorcon

Hospital Clinico Universitario "Lozano Blesa" Servicio de Oncologia Medica, Zaragoza

Hospital Universitario Central de Asturias Servicio de Oncologia, Oviedo

Instituto Valenciano de Oncologia, Valencia

\section{Sweden}

Radiumhemmet Karolinska University Hospital, Stockholm

Sahlgrenska University Hospital, Gothenburg

Central Hospital Karlstad Oncology Clinic, Karlstad

\section{Turkey}

Istanbul University Cerrahpasa School of Medicine, Istanbul

\section{Ukraine}

Municipal Institution of Healthcare VI Shapoval Regional Clinical Centre of

Urology and Nephrology Urology Department \#4, Kharkiv

Ivano-Frankivsk Regional Oncology, Dispensary Clinical Mammology Centre, Department with Urology Beds Ivano-Frankivsk

Municipal Institution, Multifield City Clinical Hospital \#4, Department of Chemotherapy, Dnipropetrovsk

Municipal Institution, Zaporizhzhia Regional Clinical Hospital of Zaporizhzhia

Regional Council, Urology Department; State Institution Zaporizhzhia

Medical Academy of Postgraduate Education of Ministry of Health of

Ukraine Chair of Urology, Zaporizhzhya

Kyiv City Clinical Hospital \#3 Urology Department, Kyiv

Municipal Institution, Dnipropetrovsk Regional Clinical Hospital named after

I.I. Mechnikov, Urology Department \#2, Dnipropetrovsk State Medical

Academy Chair of Urology, Operative Surgery and Topographic Anatomy,

Dnipropetrovsk

Regional Municipal Institution, Chernivtsi Regional Clinical Hospital,

Chemivtsi

Kyiv Oleksandrivska Clinical Hospital, Urology Department \#3, Kyiv

Uzhgorod Central City Clinical Hospital, City Oncology Centre, Uzhgorod

Municipal Clinical Medical and Preventive Treatment Institution, Donetsk

Regional Antitumour Centre, Donetsk

Medical and Preventive Treatment Institution, Volyn Regional Oncology

Dispensary, Lutsk

Lviv State Oncology Regional Treatment and Diagnostic Center, Lviv

Municipal Treatment-Prophylactic, Institution Central City Clinical Hospital,

Donetsk

(continued on following page)

Evgeniy Kopyltsov, MD, PhD

Alexey Plekhanov, MD, PhD

Denis Khvorostenko, MD

Vakhtang Shanava, MD, PhD

Natalya Rodicheva, MD

Vladimir Kheifets, MD, PhD

Boris Alekseev, MD, PhD

Alexander Zyryanov, MD

Marat Zaripov, MD

Roman Sokol, MD

Frederico Goncalves, MD, PhD

Begoña Mellado, MD

Enrique Gallardo, MD

Emilio Ríos, MD

Jose Luis Perez Gracia, MD

Begoña Pérez Valderrama, MD

Isabel Chirivella, MD

Marta Lopez-Brea Piqueras, MD

Joan Carles Galceran, MD

José Pablo Maroto, MD

Susana Hernando Polo Jesus, MD; Garcia-Donas Jimenez, MD

Alberto Saenz Cusi, MD

Emilio Esteban Gonzalez, MD; Enrique Estrada, MD

Eduardo Solsona Narbon, MD

Sten Nilsson, MD

Jan-Erik Damber, MD

Claes Ginman, MD

Can Obek, MD

Igor Antonyan, MD, PhD

Volodymyr Romanchuk, MD; Ipolit Kostinskyy, Professor $\mathrm{MD}, \mathrm{PhD}$

Igor Bondarenko, Professor, MD, PhD

Olexiy Lyulko, Professor, MD

Petro Ivashchenko, MD

Olexiy Lyulko, Professor, MD; Viktor Stus, Professor, MD

Valerii Zaitsev, Professor, MD

Sergii Pasiechnikov, Professor, MD

Yevhen Hotko, MSD, MD, PhD

Andriy Anishchenko, MD

Orest Andrusenko, MD

Yaroslav Shparyk, MD, PhD

Yuri Semyak, MD 
Table A1. Phase III Study Sites (241) in 37 Countries (continued)

\begin{tabular}{l} 
Site \\
\hline Municipal Institution of Kyiv Regional Council, Kyiv Regional Oncology \\
Dispensary, Kyiv \\
Center of Reconstructive and Restorative Medicine (University Clinic) of \\
Odesa National Medical University, Odesa \\
United Kingdom
\end{tabular}

St James University Hospital, Leeds

Royal Marsden Hospital, Sutton

Mount Vernon Hospital, Northwood

Oxford Cancer Centre, Headington

St Richard's Hospital, Chichester

Scunthorpe General Hospital, Scunthorpe

Sarah Cannon Research, London

University Hospitals Birmingham National Health Service Foundation Trust

Queen Elizabeth Hospital, Birmingham

Nottingham University Hospitals National Health Service Trust, Nottingham

\section{Canada}

The Fe/Male Health Centre, Oakville, ON

Probity Medical Research, North York, ON

Southern Interior Medical Research, Kelowna, BC

Mor Urology, Newmarket, ON

Pacific Urologic Research, Victoria, BC

St Joseph's Lifecare Centre, Brantford, ON

\section{United States}

Duke University Medical Center, Durham, NC

Peachtree Hematology-Oncology Consultants, Atlanta, GA

Urologic Consultants of Pennsylvania, Bala Cynwyd, PA

Pacific Urology Institute, Santa Monica, CA

The Sidney Kimmel Comprehensive Cancer Center at Johns Hopkins

University, Baltimore, MD

Ventura County Hematology Oncology Specialists, Oxnard, CA

Vanderbilt University Medical Center, Nashville, TN

Clinical Trials Office, Dallas, TX

University of Pittsburgh Physicians Department of Urology, Pittsburgh, PA

Premier Medical Group, Poughkeepsie, NY

Midwest Urology Associates, Melrose Park, IL

Lawrenceville Urology, Lawrenceville, NJ

Capitol Comprehensive Cancer Care Clinic, Jefferson City, MO

Carolina Urology Partners, Concord, NC

Palm Beach Urology Associates, Wellington, FL

Roswell Park Cancer Center Institute, Buffalo, NY

Grand Strand Urology, Myrtle Beach, SC

Lancaster Urology, Lancaster, PA

Boise Urology, Meridian, ID

Metropolitan Urology, Jeffersonville, IN

Frankel, Reed \& Evans, Burien, WA

Virginia Oncology Associates, Norfolk, VA

Virginia Cancer Specialists, Fairfax, VA

Texas Oncology-Baylor Charles A. Sammons Cancer Center, Dallas, TX

Blue Ridge Cancer Care, Roanoke, VA

Willamette Valley Cancer Institute and Research Center, Eugene, OR

Comprehensive Cancer Centers of Nevada, Las Vegas, NV

Raleigh Hematology Oncology Associates, DBA Cancer Centers of North

Carolina, Raleigh, NC

University of Utah/Huntsman Cancer Center, Salt Lake City, UT

Associates in Oncology/Hematology, Rockville, MD

Oncology Specialists, Park Ridge, IL

John Theurer Cancer Center at Hackensack, Hackensack, NJ

Redwood Regional Medical Group, Santa Rosa, CA

Arizona Oncology Associates, Tucson, AZ

Tufts Medical Center, Boston, MA

lurii Golovko, MD

Nataliia Tavartkiladze, MD

William Cross, MD

Robert Huddart, MD

Peter Hoskin, MD

Andrew Protheroe, MD

James Hicks, MD; Paul Carter, MD

Sanjay Dixit, MD

Simon Chowdhury, MA, MBBS, MRCP, PhD

Nicholas James, MD

Santhanam Sundar, MD

Richard Casey, MD

Stanley Flax, MB, BCh

Thomas Kinahan, MD

Morrie Liquornik, MD

Gary Steinhoff, MD

Wilson Leung, MD

Andrew Armstrong, MD

Vasileios John Assikis, MD

Laurence H. Belkoff, DO

Stanley Brosman, MD

Michael Carducci, MD

Kevin O. Chang, MD

Sam Chang, MD

James Cochran, MD

Jeffrey Gingrich, MD

Evan R. Goldfischer, MD

Richard G. Harris, MD

Gary S. Karlin, MD

Ali Khojasteh, MD

David U. Lipsitz, MD, FACS, CP

Georgis Patsias, MD

Roberto Pili, MD

Neal Shore, MD, FACS

Paul R. Sieber, MD

Joseph H. Williams, MD

James L. Bailen, MD

Jeffrey M. Frankel, MD

Mark T. Fleming, MD

Alexander I. Spira, MD

Thomas E. Hutson, DO

Mark D. Kochenderfer, MD

Joseph A. Fiorillo, MD; John R. Caton Jr, MD

Nicholas J. Vogelzang, MD

William R. Berry, MD

Neeraj Agarwal, MD

Manish Agrawal, MD

Timothy Lestingi, MD; Chadi Nabhan, MD

Robert Alter, MD

Wes S. Lee, MD

Christopher Di Simone, MD

Paul Mathew, MD 
Sternberg et al

Table A2. Other Secondary Efficacy End Points

\begin{tabular}{|c|c|c|c|c|c|c|c|}
\hline \multirow[b]{2}{*}{ Outcomes } & \multicolumn{2}{|c|}{$\begin{array}{l}\text { Tasquinimod } \\
(\mathrm{n}=832)\end{array}$} & \multicolumn{2}{|c|}{$\begin{array}{l}\text { Placebo } \\
(\mathrm{n}=413)\end{array}$} & \multirow[b]{2}{*}{$\mathrm{HR}$} & \multirow[b]{2}{*}{$95 \% \mathrm{Cl}$} & \multirow[b]{2}{*}{$P$} \\
\hline & Median (months) & $95 \% \mathrm{Cl}$ & Median (months) & $95 \% \mathrm{Cl}$ & & & \\
\hline \multicolumn{8}{|l|}{ New bone lesion } \\
\hline Local & 8.3 & 6.0 to 9.5 & 4.5 & 3.1 to 5.6 & 0.723 & 0.616 to 0.848 & $<.001$ \\
\hline Central & 8.1 & 6.0 to 8.5 & 4.8 & 3.1 to 5.6 & 0.735 & 0.623 to 0.867 & $<.001$ \\
\hline \multicolumn{8}{|l|}{ New soft tissue lesion } \\
\hline Local & 19.4 & 16.6 to 25.3 & 11.1 & 8.6 to 16.4 & 0.612 & 0.493 to 0.760 & $<.001$ \\
\hline Central & 20.5 & 19.3 to $N R$ & 19.1 & 11.5 to $\mathrm{NR}$ & 0.678 & 0.531 to 0.866 & .002 \\
\hline \multicolumn{8}{|c|}{ First radiologic or symptomatic progression } \\
\hline Local & 4.8 & 4.1 to 5.5 & 3.2 & 2.9 to 4.2 & 0.812 & 0.714 to 0.925 & .002 \\
\hline Central & 5.2 & 4.4 to 5.6 & 3.7 & 3.1 to 4.4 & 0.849 & 0.745 to 0.967 & .013 \\
\hline \multicolumn{8}{|c|}{ First radiologic or symptomatic progression or death } \\
\hline Local & 4.8 & 4.0 to 5.5 & 3.2 & 2.9 to 4.1 & 0.812 & .716 to .922 & .001 \\
\hline Central & 5.2 & 4.4 to 5.6 & 3.6 & 3.1 to 4.3 & 0.845 & 0.744 to 0.959 & .009 \\
\hline Tumor-related pain progression* & 5.6 & 4.9 to 6.0 & 8.3 & 6.7 to 10.8 & 1.259 & 1.097 to 1.445 & $<.001$ \\
\hline KPS deterioration & 11.7 & 10.3 to 13.6 & 17.4 & 14.5 to 19.1 & 1.292 & 1.110 to 1.505 & $<.001$ \\
\hline PSA doubling time & 5.2 & 4.5 to 5.6 & 3.3 & 2.9 to 4.0 & 0.734 & 0.631 to 0.853 & $<.001$ \\
\hline
\end{tabular}

Abbreviations: HR, hazard ratio; KPS, Karnofsky performance status; NR, not reached; PSA, prostate-specific antigen.

*Including palliative interventions. 